Gresham Committee reported that they had agreed with the Mercers' Company upon a scheme by which the open area of the Royal Exchange should be roofed over at a cost of 10,000l. Does this mean that the funds of the Giesham Estate are pxrticularly flourishing just now, or that they are to be burdened with a new liability which will indefinitely postpone the time when there may be a surplus to be devoted to that advancement of science which Sir Thomas Gresham had in view in forming Gresham College? It is not long since some of the bonds, which represent money borrowed on the Gresham Estate for the building of the Royal Exchange, were advertised for repayment out of its surplus annual income, which afforded a hope that a good time for the scientific part of Sir Thomas Gresham's bequest might be drawing nigh. The public would be glad to know whether this hope is to be falsified or not. January 20

\section{Siwalik Carnivora}

MAY I ask space to thank your correspondents $f, r$ their answer to my previous inquiries concerning collections of Siwalik fosils in England, (many of which I have not yet had an opportu ity of visiting,) and to add that I am now about undertaking the description of Siwalik Carnivora for the Indian Government? All remains of this order are very scarce, and in general fragmentary, and every specimen is, therefore, im ?ortant. If any specimens exist in any provincial collections, I should be very glad of any information regarding them, and if possible of the opportunity of describing them in my forthcoming memoir. Any specimens sent to me, to the care of Dr. H. Woodward, F.R.S., British Museum (Natural History), Cromwell Rnad, S.W., will be thankfully received, and duly returned after comparison and description, if necessary.

The Lodge, Harpenden, Herts, January 17

\section{Earthquakes}

EARTHOUAKE phenomena are extremely rare in this highly favoured part of the world; but we had a very decided shake near the close of the year I882. It occurred last night (Sunday, December $3 \mathbf{I}$ ) at about five minutes past ten o'clock, Halifax time, as nearly as can be determined at present. My observation was made at Lucyfield, ten miles north from the city of Halifax; the house stands on a rounded hill forined of unaltered drift, overlying slate rock, and at an elevation of absut $35^{\circ}$ feet above sea-level.

The air was perfectly still. There was a sudden rumble as of heavy waggons on a hard rond at some little distance, then the sound became louder, I may say deafening, as of heavy loaded waggons running close to the wall; or of a heavy railway train running through a reverberating cutting; then the noise seemed overhead as if caused by rolling heavy furniture on the upper floor; there was a slight vibration of the building, as if some. thing large and heavy had struck the roof, icicles fell from the eaves, fragments of plaster fell down behind the lathing of the walls, and there was a sound like a sudden gust of wind upon the windows and walls outide (there was no wind however). Suddenly noise and vibration ceased, and all was perfectly still. Passing outside, to look for some cau :e for these remarkable phenomena, nothing particular was noticeable. The country was covered with a thick white mantle of snow, the air was perfectly calm, there had been no rain drops, nor hail, but a faint flash of lightning (unaccompanied by thunder) occurred about a minute and a half or two minutes after cessation of the shock.

For two or three days prior to the shock, the temperature did not fluctuate much. The thermometer stood at zero centigrade $\left(32^{\circ} \mathrm{F}\right.$.) at sunset on the 3 Ist and has not varied much since; it was within a degree of the same at sunset of the previous day, but went down at night, rising again in the morning. During the day (3rst) the sky was clear with some light fleecy clouds, wind northerly, but veered round to south-west about sunset, and the sky became overcast with clouds; later the clouds seemed to clear away, but the air became $f$ ggy, and was so at the time of the shock. (About _Truro I am informed the sky was "clear and starry.") The air had been in a highly electric state during the afternoon and evening.

The earthquake sh ock lasted, as nearly as I can compute from recalling circumstances, something less than a minute, certainly more than half a minute, but probably not more than a whole one. I cannot indicate with any degree of certainty the direction of oscillation; so far as a retrospect of circumstances and sensations indicate, the apparent movement was from south-west to north-east.

Most persons in the city of Halifax to whom I have spoken to day ob :erved the shock more or less distinctly, but it does not appear to have been nearly as violent in the city as in some other places. I ascertained from the conductor of the morning railway train that the shock was felt more or leis severely all along the journey traversed by his train this morning, viz. from Truro to Halifax, a distance of sixty-one mile;. At Shubenacadie, nearly thirty miles from my point of observation, flower-pots in the railway station house were toppled over on the window-sill and rolled upon the floor.

I have jotted down these particulars, thinking they may possibly prove of some interest if compared with the observations of others at different points.

Dalhousie College, Halifax, Nova Scotia, January $x$

A sHock of earthquake was felt in this district on Tuesday, January i6, about 5 p.m. Comparatively few persons perceived it, but to those who did it was a striking phenomenon. The following report has been handed to me by a trustworthy observer :-

"About 5 p.m. on Tuesday, January I6, I was standin $y$ in a room, leaning against the foot of an iron bedstead, and facing a window, in front of which, on a table, was a cage containing one of the small African parrakeets known as love birds. The room was perfectly quiet, when this bird, whish had settled itself for the night, surprised me by cranin $r$ out its neck and flattening its plumage with every appearance of alarm, without any sound or movement on my part, or anything in the room which could possibly have frightened it. Inmediately afterwards the iron bedstead I was leanin r against, as well as the floor, trembled sufficiently to make me wonder what on earth was going on, especially as I heard no sound sufficient to account for it. The trembling ceased in a few seconds, and, while I was still wondering, returned in a greater degree than before, lasting this time about five seconds. The feeling I experiensed was similar to that of standing on a bridge while a load was passing over. The second time I speedily came to the conclusion that it was caused by an earthquake."

Clifton, January 20

George F. Burder

I SHALL feel obliged if you will put on recors in your columns that an earthquake was felt at Hastings by my sister and myself in separate rooms, on Tuesday morning last, the r6th inst., at $9 \frac{1}{2}$ minutes past 9 a.m. The undul atione were between E.S.E. and W.N.W., and lasted ab out 4 second .

R. H. TIDDEMAN
H.M. Geological Survey, 28, Jermyn Street, S.W., Jan. 20

\section{The Sea Serpent}

BeLIEVING it to be desirable that every well-authenticated observation indicating the existence of large sea serpents should be permanently regi-tered, I send you the following particulars.

About three p.m. on Sunday, September 3, 1882, a party of gentlemen and ladies were standing at the northern extremity of Llandudno pier, looking towards the open sea, when an unusual object was observed in the water near to the Little Orme's Head,

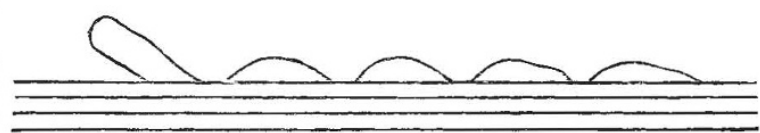

travellin rapidly westwards towards the Great Orme. It appeared to be just outside the mouth of the bay, and would therefore be about a mile distant from the observers. It was watched for about two minutes, and in that interval it traversed about balf the width of the bay, and then suddenly disappeared. The bay is two miles wide, and therefore the object, whatever it was, must have travelled at the rate of thirty miles an hour. It is estimated to have been fully as $1 \mathrm{nng}$ as a large steamer, say 200 feet; the rapidity of it: motion was particularly remarked as being greater than that of any ordinary vessel. The colour 